\title{
Sludge Accumulation in Two Anaerobic/Facultative Lagoons Treating Swine Manure from Breeding Farms in OKLahoma
}

\author{
D. W. Hamilton
}

\begin{abstract}
Sludge stage and volume were monitored in two lagoons (OK1 and OK2) treating manure from swine breeding farms for a period of 9 years. Solids management differed between the two lagoons. Sludge was left relatively undisturbed in lagoon OK1, whereas solids were removed with each irrigation in lagoon OK2. When left undisturbed, sludge accumulated in a pattern consistent with the complex accumulation model proposed by earlier researchers. Sludge accumulated faster when solids were removed during irrigation compared to the lagoon in which solids were left undisturbed. Accumulation in both disturbed and undisturbed lagoons occurred at a rate less than current ASABE and NRCS standards. Onset of rapid accumulation appears to be related to volumetric organic loading rate rather than separation distance between top of the sludge and the liquid surface. Critical organic loading rates contained in the current standards appear to be adequate to determine the onset of rapid sludge accumulation.
\end{abstract}

Keywords. Agricultural waste, Biological treatment, Lagoon, Sludge, Solids, Swine manure.

$\mathrm{E}$ arly animal manure treatment lagoons were designed on the premise that manure solids were completely digested in the lagoon. It soon became apparent that solids do not disappear from manure treatment lagoons. Booram et al. (1975) observed that sludge accumulates in a dual-rate process. Accumulation is rapid at first, but slows as the lagoon ages. A number of groups began looking into sludge accumulation during the late 1970s (Nordstedt and Baldwin, 1975; Fulhage, 1980; Smith, 1980). These studies concluded that sludge accumulates thickest in the flat sections of the lagoon bottom and thinner on the sloping sides. They also divided accumulated sludge into two fractions: the sludge bed (inert, dense sludge that is measurable by feel) and the sludge blanket (a biologically active sludge above the sludge bed that cannot be directly measured by feel).

Smith (1980), using field observations and previous laboratory analysis by Humenik and Overcash (1976), determined that sludge accumulates in swine treatment lagoons based on first-order kinetics. He proposed the following model for sludge accumulation:

$$
S=\left(M_{v} / k\right)\left(1-\mathrm{e}^{-k t}\right)
$$

where

$S \quad$ = accumulated sludge solids (mass)

$M_{v}=$ volatile solids loading rate (mass/time)

$k=$ first-order proportionality constant $\left(\right.$ time $\left.^{-1}\right)$

$t=$ time since volatile solids loading began (time).

Submitted for review in June 2008 as manuscript number SE 7564; approved for publication by the Structures \& Environment Division of ASABE in February 2010.

The author is Douglas Wayne Hamilton, ASABE Member Engineer, Associate Professor, Department of Agricultural and Biosystems Engineering, Oklahoma State University, 226 Agricultural Hall, Stillwater, OK 74078-6021; phone: 405-744-4089; fax: 405-744-6059; e-mail: dhamilt@okstate.edu.
If $k$ is constant, then equation 1 implies that sludge eventually reaches a constant mass equal to $M_{v} / k$. Barth and Kroes (1985) stated that a constant sludge mass cannot be reached since a portion of the loaded solids cannot be digested. The undigested solids accumulate in the sludge bed as inert sludge. Through observation, Barth and Kroes (1985) suggested that sludge accumulation follows the complex accumulation model shown in figure 1 . If the inert sludge bed is added to the active sludge blanket described by equation 1 , then the mass of accumulated sludge solids $(S)$ at any time $\left(t^{\prime}\right)$ between a lag time before sludge begins to accumulate $\left(t_{l}\right)$ and the critical time $\left(t_{c}\right)$ when the lagoon begins to show signs of failure can be determined by:

$$
S=\left(M_{T} R / k\right)\left(1-\mathrm{e}^{-k t^{\prime}}\right)+M_{T}(1-R) t^{\prime}
$$

where

$$
\begin{aligned}
S= & \text { accumulated sludge total solids (mass) } \\
M_{T}= & \text { total solids loading rate (mass/time) } \\
R= & \text { steady-state solids removal fraction (mass re } \\
& \text { moved/mass loaded) } \\
t^{\prime}= & \text { time after lag time has ended (time) }
\end{aligned}
$$

The mass of sludge solids $(S)$ given in equation 2 is the combination of the sludge bed and sludge blanket. Although implied in the complex accumulation model, a separate, dis-

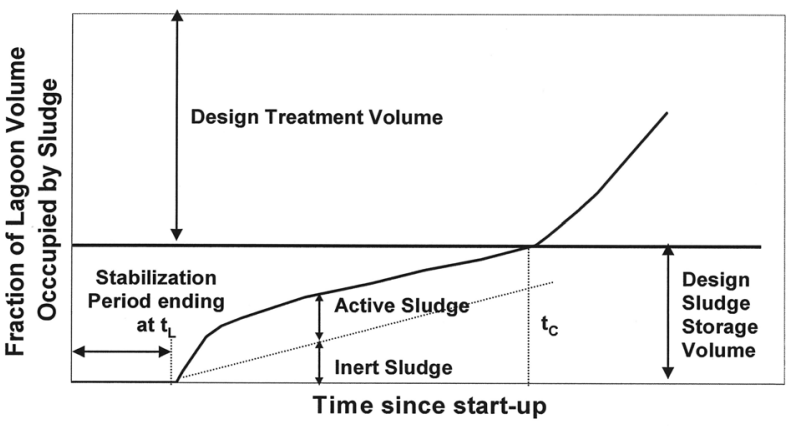

Figure 1. Complex sludge accumulation model (Barth and Kroes, 1985). 
Table 1. Lagoon design factors from the rational design standard (Barth, 1985).

\begin{tabular}{lcccc}
\hline Design Factor & Swine & Layers & Pullets & Dairy \\
\hline $\begin{array}{l}\text { Volumetric loading rate for } \\
\text { minimum treatment volume }\end{array}$ & 0.10 & 0.17 & 0.17 & 0.10 \\
$\left(\mathrm{~kg} \mathrm{VS} \mathrm{m}^{-3} \mathrm{~d}^{-1}\right)$ & & & & \\
\hline $\begin{array}{l}\text { Volumetric loading rate for } \\
\left.\text { odor control (kg VS m}{ }^{-3} \mathrm{~d}^{-1}\right)\end{array}$ & 0.061 & 0.037 & 0.037 & 0.10 \\
\hline $\begin{array}{l}\text { Sludge accumulation factor } \\
\left(\mathrm{m}^{3} \text { sludge kg-1 } \mathrm{TS}\right)\end{array}$ & 0.00303 & 0.00184 & 0.00284 & 0.00455 \\
\hline a] at $K($ Van't Hoff-Arrhenius temperature factor $)=1.0$. & & &
\end{tabular}

tinguishable bed of inert material does not necessarily exist below an active sludge blanket. It is important to note that equation 2 determines the mass of accumulated sludge solids based on total solids loading $\left(M_{T}\right)$. In addition, the fraction of total solids that can be reduced in the lagoon $(R)$ is neither the volatile solids fraction nor the biologically digestible fraction. The primary pathway of sludge removal may be biological conversion of volatile solids to gas, but solids removal may also occur through biological conversion to organic liquids, dissolution of inorganic solids, and removal of intact solids through effluent dewatering. Solids may also be added to the sludge layer by precipitation of salts. The parameters $k$ and $R$, therefore, depend on the entire lagoon function and operation: the mix of biological communities inhabiting the lagoon, settling of influent and precipitating solids, and removal of soluble materials.

The complex accumulation model agrees with the observation of Booram et al. (1975) that sludge accumulates in a two-rate process; furthermore, accumulation does not proceed indefinitely without loss of treatment efficiency. Barth and Kroes (1985) stated that at $t_{c}$, accumulating solids reduce the liquid volume inhabited by microbial communities consuming the end-products of solids digestion to the point that digestion slows, and solids accumulate rapidly. This suggests that reaching a critical volumetric organic loading rate causes the onset of rapid sludge accumulation. Table 1 gives loading rates at which the accelerated sludge buildup would commence for swine, dairy, and poultry lagoons. The problem with the acceleration of sludge accumulation is that soon after it begins, the entire volume of the lagoon may be filled with sludge, and treatment of liquids will no longer occur.

It is much easier to measure the volume of accumulated sludge than the mass of sludge solids. In suggesting a design standard for lagoons, Barth (1985) substituted sludge volume for mass. He also made a significant deviation from the complex accumulation model. In the rational design standard, Barth (1985) presented a linear accumulation factor based on total solids loading to determine sludge storage volume. For swine manure, and units of $\mathrm{kg}$ and $\mathrm{m}^{3}$, the accumulation equation is:

$$
V=0.00303 M_{T} t
$$

Equation 3 was incorporated into both the NRCS (USDANRCS, 1992) and ASAE (ASAE Standards, 2004) standards for lagoon design. Linear accumulation factors for dairy and poultry lagoons are also given in table 1 .

The linear accumulation factors given in table 1 have been a source of controversy in the years following their publication. A number of studies (Bicudo et al., 1999; Anderson et al., 2000; Tyson et al., 2002; Morton et al., 2003; Mukhtar et al., 2004; Fulhage et al., 2005) were undertaken primarily to show that the linear factors overestimate the volume occupied by accumulating sludge; indeed, these studies measured accumulation rates $1 / 4$ to $3 / 4$ those used in the ASABE and NRCS standards.

One potential flaw of these studies is that they measured sludge volume at one point in time and extrapolated back to lagoon start-up to calculate a linear rate based on TS loading. To evaluate the complex sludge accumulation model, one must periodically evaluate sludge accumulation over an extended period of time, ideally from lagoon start-up until the onset of rapid accumulation. This article reports sludge accumulation data collected over a 9-year period from two lagoons of similar size and loading. Both lagoons were followed from within two years of start-up until the commencement of rapid sludge accumulation.

\section{ObJectives}

- Determine the rate of sludge volume accumulation with respect to total solids loading for small, swine breeding and gestation farms.

- Compare the patterns of sludge accumulation to the complex accumulation model.

- Correlate the onset of rapid sludge accumulation to lagoon operational parameters.

\section{Methods ANd Materials}

Two lagoons treating manure generated by sow-gestationto-weaning farms were chosen for this study. The operators produced weanling pigs under contract for different integrators, and the lagoons had radically different management schemes. Breeding and gestation farms were chosen due to their relatively constant solids loading rate $\left(M_{t}\right)$ compared to other swine operations. Characteristics of the lagoons, labeled $\mathrm{OK} 1$ and $\mathrm{OK} 2$, are given in table 2. Both lagoons are oriented so that their length is aligned on an east-west axis. Manure solids production for both farms was determined using the recorded feed intake of pigs (Cumba, 1998) and ASABE Standard D384.2 (ASABE Standards, 2005). Both lagoons were designed by the USDA-NRCS based on the statelevel standards current at the time of construction. Under this standard, lagoon volume was determined by dividing the daily volatile solids production by the maximum organic loading rate of 0.092 to $0.093 \mathrm{~kg} \mathrm{VS} \mathrm{m}^{-3} \mathrm{~d}^{-1}$ and adding an extra foot for sludge accumulation. It was assumed that sludge solids would be removed with irrigation.

In the original rational design method (Barth, 1985), the organic loading rate to determine minimum treatment volume (table 1) was calculated by dividing the mass of volatile solids added each day by the volume of liquid above the sludge layer. The loading rate for odor control was determined by dividing the mass of volatile solids added each day by the total volume of the lagoon (both the treatment and sludge storage volumes, table 1). Loading rates were adjusted for local climatic conditions by multiplying the calculated rate with a Van't Hoff-Arrhenius temperature factor $(K)$. A map of iso- $K$ lines for the continental U.S. was provided by Barth (1985). $K$ for the location of OK1 is 0.80 ; therefore, the volumetric loading rate to determine minimum treatment volume is $0.080 \mathrm{~kg} \mathrm{VS} \mathrm{m}^{-3} \mathrm{~d}^{-1}$ for the location of OK1. Likewise, the odor control loading rate is $0.049 \mathrm{~kg} \mathrm{VS} \mathrm{m}^{-3} \mathrm{~d}^{-1}$ at this location. $K$ for the location of OK2 is 0.82 (Barth, 1985); 
Table 2. Test lagoons: locations, dimensions, and organic matter loading rates.

\begin{tabular}{lcc}
\hline & Lagoon OK1 & Lagoon OK2 \\
\hline Location & Pottawatomie & LeFlore \\
& County, Okla. & County, Okla. \\
& $35^{\circ} 10^{\prime} \mathrm{N}$, & $35^{\circ} 05^{\prime} \mathrm{N}$, \\
$97^{\circ} 00^{\prime} \mathrm{W}$ & $94^{\circ} 30^{\prime} \mathrm{W}$
\end{tabular}

\begin{tabular}{|c|c|c|}
\hline \multicolumn{3}{|l|}{ Bottom dimensions } \\
\hline Width & $24.4 \mathrm{~m}$ & $21.3 \mathrm{~m}$ \\
\hline Length & $53.3 \mathrm{~m}$ & $44.2 \mathrm{~m}$ \\
\hline \multicolumn{3}{|c|}{ Maximum drawdown dimensions } \\
\hline Depth & $2.22 \mathrm{~m}$ & $2.29 \mathrm{~m}$ \\
\hline Width & $36.3 \mathrm{~m}$ & $38.4 \mathrm{~m}$ \\
\hline Length & $65.2 \mathrm{~m}$ & $61.0 \mathrm{~m}$ \\
\hline Volume & $4,050 \mathrm{~m}^{3}$ & $3,540 \mathrm{~m}^{3}$ \\
\hline \multicolumn{3}{|c|}{ Maximum operating dimensions } \\
\hline Depth & $2.59 \mathrm{~m}$ & $3.20 \mathrm{~m}$ \\
\hline Width & $39.0 \mathrm{~m}$ & $43.9 \mathrm{~m}$ \\
\hline Length & $68.0 \mathrm{~m}$ & $66.8 \mathrm{~m}$ \\
\hline Volume & $5,180 \mathrm{~m}^{3}$ & $5,890 \mathrm{~m}^{3}$ \\
\hline Sideslope & $2.7: 1$ & $3.5: 1$ \\
\hline Farm solids production & $\begin{array}{l}315 \mathrm{~kg} \mathrm{TS} \mathrm{d}^{-1} \\
280 \mathrm{~kg} \mathrm{VS} \mathrm{d}^{-1}\end{array}$ & $\begin{array}{l}250 \mathrm{~kg} \mathrm{TS} \mathrm{d}^{-1} \\
220 \mathrm{~kg} \mathrm{VS} \mathrm{d}^{-1}\end{array}$ \\
\hline
\end{tabular}

Volumetric loading at maximum drawdown

before sludge accumulation

$$
0.069 \mathrm{~kg} \mathrm{VS} \mathrm{m}^{-3} \mathrm{~d}^{-1} \quad 0.062 \mathrm{~kg} \mathrm{VS} \mathrm{m}^{-3} \mathrm{~d}^{-1}
$$

Surface loading at maximum drawdown

$$
1,200 \mathrm{~kg} \mathrm{VS} \mathrm{ha}^{-1} \mathrm{~d}^{-1} \quad 940 \mathrm{~kg} \mathrm{VS} \mathrm{ha}^{-1} \mathrm{~d}^{-1}
$$

therefore, the minimum treatment loading and odor control rates for OK2 are 0.082 and $0.050 \mathrm{~kg} \mathrm{VS} \mathrm{m}^{-3} \mathrm{~d}^{-1}$, respectively. The actual initial organic loading rates for both lagoons at the maximum drawdown level before sludge accumulation were about halfway between Barth's odor control and maximum loading rates (table 2).

\section{MANAGEMENT OF LAgOON OK1}

Operation of OK1 began in July 1994. Manure was removed from buildings using pit recharge. All manure entered the lagoon through a single pipe located in the southeast corner of the lagoon. Length of time between pit recharge was 7 days or greater. The operator rarely irrigated more than two or three times each year, and effluent was only applied in late spring and early fall. Effluent was removed from the upper $1 \mathrm{~m}$ of the lagoon using a floating intake. Sludge was not removed, nor was the lagoon agitated during the study period. The operator agitated and partially removed sludge from the lagoon in the spring of 2004.

\section{MANAGEMENT OF LAGOON OK2}

Hogs were placed on farm OK2 in December 1994. Farm OK2 used an under-slat flushing system to remove manure from buildings. Flushing frequency was $30 \mathrm{~min}$. Manure entered the lagoon from the farrowing and breeding/gestation buildings via separate pipes. Both outfalls were located at the eastern end of the lagoon. Effluent was continuously recycled to flush tanks from the upper $1 \mathrm{~m}$ of the lagoon using floating intakes located within $15 \mathrm{~m}$ of the breeding/gestation building outfall. Effluent was irrigated frequently from lagoon OK2, i.e., 7 to 10 times a year, and irrigation occurred during any month of the year. During irrigation, the intake line was allowed to settle into the sludge layer before pumping began with the intent of removing sludge solids. The operator be- came concerned about sludge accumulation in the fall of 2000. He purchased a propeller-type agitator in the spring of 2001 and agitated the sludge layer each time effluent was applied after June 2001.

\section{Measurement of Sludge Volume Accumulation}

An intensive survey was made of each farm and lagoon during the first year of the study. Elevations relative to a permanent benchmark were made using a dumpy level. Horizontal measurements were made with a surveying wheel. The lagoons were divided into three roughly equal sections by transect lines running the width of the lagoon. The location of each transect was marked so that it could be used in the following years. Transects $(0+80,1+60)$ were made 24 and $49 \mathrm{~m}$ west of the easternmost waterline of 21 May 1996 in lagoon OK1. Transects were made 21 and $43 \mathrm{~m}(0+70,1+40)$ west of the easternmost waterline of 23 May 1996 in lagoon OK2.

Sludge and bottom depths were determined using a T-stick similar to that used by Barth and Kroes (1985). A rope was floated along each transect line. Soundings of the feelable sludge and the lagoon bottom were made every $3.04 \mathrm{~m}(10 \mathrm{ft})$ along the transect lines from a boat connected to the marked rope. First the stick was lowered until resistance was felt, indicating the top of the sludge. The stick was then pushed through forcefully until it came to a complete rest on the lagoon bottom. Since the transect length depends on the water level of the lagoon, the center point of each transect was determined after sampling. Average sludge and bottom elevations were determined using the 12 data points within $8.5 \mathrm{~m}$ of the center line on both transects. The feelable sludge stage above the lagoon bottom was calculated as the difference in average sludge elevations and average lagoon bottom elevation. Feelable sludge volume was determined using equation 4:

$$
V=W L d+(W+L) s d^{2}+1.33 s^{2} d^{3}
$$

where

$$
\begin{aligned}
W= & \text { lagoon bottom width (length) } \\
L= & \text { lagoon bottom length (length) } \\
s= & \text { sideslope of lagoon embankment (length lateral/ } \\
& \text { length vertical) } \\
d= & \text { sludge stage (length) } .
\end{aligned}
$$

The volume determined from equation 4 is the storage volume occupied by sludge as defined by standards (ASAE Standards, 2004, USDA-NRCS, 1992). Sludge adhering to the lagoon slopes does not figure into storage volume calculations.

\section{Results AND Discussion}

\section{Sludge Stage and Volume over Time}

Sludge and lagoon bottom measurements along transects $0+80$ and $1+60$ in lagoon $\mathrm{OK} 1$ at selected sampling dates are given in figure 2 . Average feelable sludge and average bottom elevations above the lowest point measured on the lagoon bottom, as well as feelable sludge stage and feelable sludge volumes, for OK1 are given in table 3. Figure 2 shows that if left undisturbed, sludge will first fill the irregular spaces in the lagoon bottom, and then accumulate by seeking a level surface. The evenness of sludge accumulating in lagoon OK1 can be sensed by comparing the standard deviations (SD) of feelable sludge observations in table 3 to the 
May 21, 1996
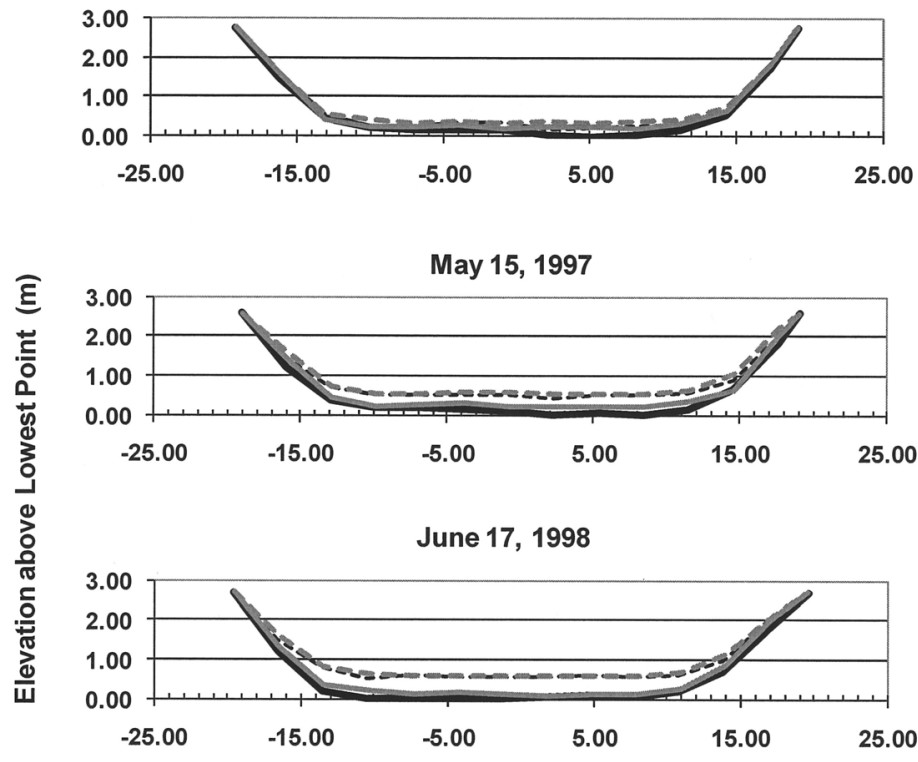

May 22, 2002

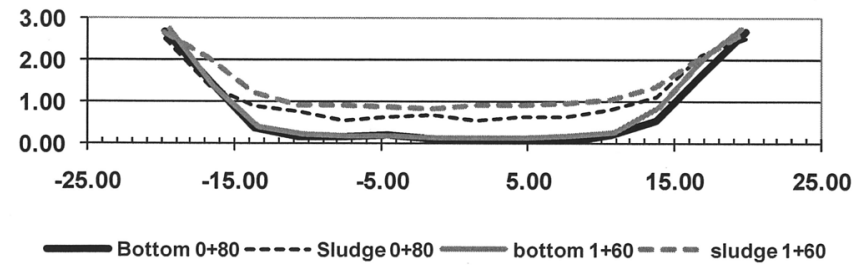

Distance from Centerline (m)

Figure 2. Feelable sludge and lagoon bottom measurements, lagoon OK1.

Table 3. Observed average feelable sludge elevations, and calculated average feelable sludge stage and volume in lagoon OK1 from 21 May 1996 to 11 June 2003.

\begin{tabular}{cccccc}
\hline & $\begin{array}{c}\text { Age } \\
\text { (years since } \\
\text { start-up) }\end{array}$ & $\begin{array}{c}\text { Bottom } \\
\text { Elevation }(\mathrm{m}), \\
\text { mean }(\mathrm{SD})\end{array}$ & $\begin{array}{c}\text { Feelable Sludge } \\
\text { Elevation }(\mathrm{ft}), \\
\text { mean }(\mathrm{SD})\end{array}$ & $\begin{array}{c}\text { Feelable Sludge } \\
\text { Stage } \\
(\mathrm{m})\end{array}$ & $\begin{array}{c}\text { Feelable Sludge } \\
\text { Volume } \\
\left(\mathrm{m}^{3}\right)\end{array}$ \\
\hline Sampling Date & 1.86 & $0.16(0.0855)$ & $0.30(0.071)$ & 0.15 & 190 \\
15 May 1996 & 2.83 & $0.16(0.0965)$ & $0.54(0.040)$ & 0.38 & 530 \\
17 June 1998 & 3.91 & $0.09(0.0575)$ & $0.59(0.023)$ & 0.49 & 700 \\
11 August 1999 & 5.04 & $0.16(0.10)$ & $0.73(0.13)$ & 0.57 & 810 \\
7 July 2000 & 5.93 & $0.19(0.13)$ & $0.83(0.086)$ & 0.64 & 1,000 \\
20 June 2001 & 6.87 & $0.20(0.15)$ & $0.91(0.049)$ & 0.71 & 1,100 \\
22 May 2002 & 7.78 & $0.18(0.12)$ & $0.94(0.077)$ & 0.76 & 1.01 \\
11 June 2003 & 8.82 & $0.21(0.14)$ & $1.22(0.141)$ & & 1,550 \\
\hline
\end{tabular}

SD of bottom elevation observations. After the first year of observation, SD of sludge observations was generally less than or equal to that of the bottom observations. Feelable sludge stage and volume in OK1 are plotted against lagoon age in figure 3. Accumulation in OK1 followed the complex accumulation model with a lag time of approximately 1.5 years and rapid accumulation occurring after 8 years. It was not possible to determine if sludge continued to accumulate at the rapid rate beyond year 9 because the producer began agitating and removing sludge during year 10 .

Sludge and lagoon bottom measurements along transects $0+70$ and $1+40$ in lagoon OK2 are given in figure 4. Average feelable sludge and bottom elevations, feelable sludge stage, and feelable sludge volume for OK2 are given in table 4. Feelable sludge stage and volume versus lagoon age is given in figure 5. It is difficult to draw conclusion about accumulation in OK2 since the producer removed solids sludge during irrigation. Sludge accumulation is more erratic in OK2 than in OK1; the SD of feelable sludge elevation observations are always greater than SD of lagoon bottom observations. Two hypotheses are given for the apparent decline in sludge stage between years 2.42 and 4.65 . The first explanation is that the average values are real, and demonstrate that the producer was able to reduce sludge accumulation early in the lagoon's life by removing solids with irrigation. The second explanation is that the value for year 4.65 is low due to the fact that 


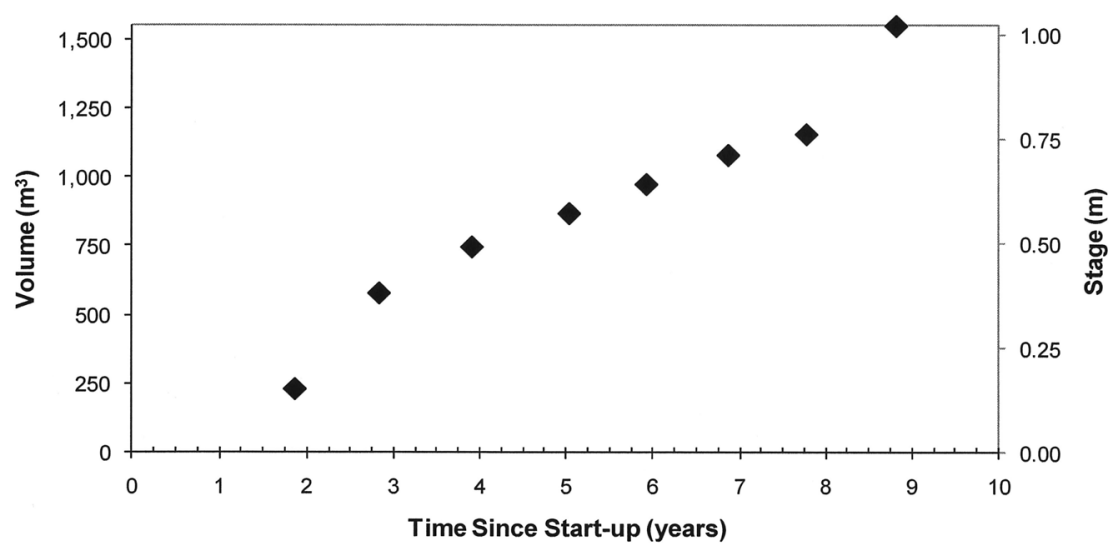

Figure 3. Feelable sludge stage and volume versus time since start-up, lagoon OK1.

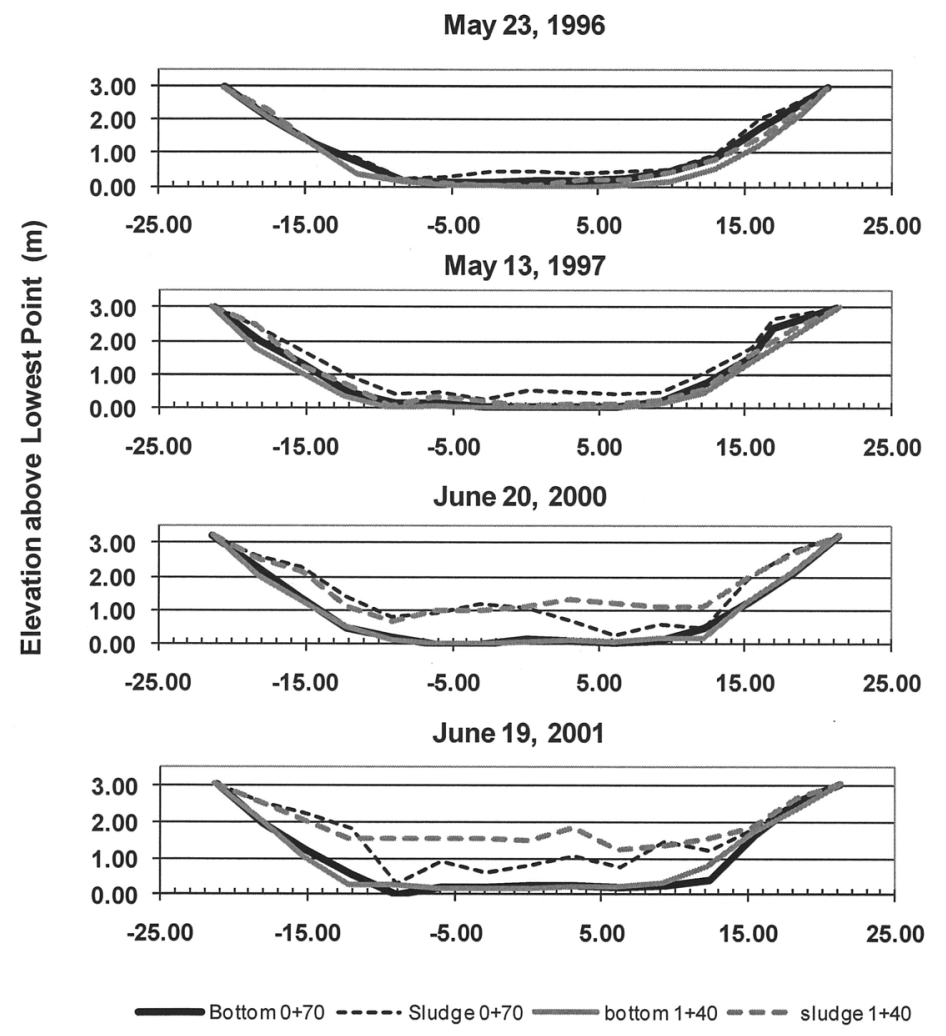

Distance from Centerline $(\mathrm{m})$

Figure 4. Feelable sludge and lagoon bottom measurements, lagoon OK2.

the lagoon was turning over during sampling. Although the sampling date does not fall within the period of autumnal thermal instability for the area (Hamilton and Cumba, 2000), field notes taken at the time of sampling indicate a greater than normal mat of scum floating on the lagoon. Rapid accumulation appears to occur after 6.46 years of operation. The apparent reduction in sludge stage at 8.41 years occurs after the producer began mechanical agitation during effluent irrigation.

\section{SLUdGe Volume Versus Solids LoAding}

Sludge volume is plotted versus mass of solids added for both OK1 and OK2 in figure 6 . Apart from the low volume measured for lagoon OK2 at 4.65 years, both lagoons follow a similar trend of accumulation, with OK2 increasing at a slightly faster rate. This is contrary to the notion that sludge solids would not accumulate if they were purposely removed during irrigation.

Using only those points that represent the linear accumulation portion of the complex model, OK1 has an accumulation rate of $0.0010 \mathrm{~m}^{3} \mathrm{~kg}^{-1} \mathrm{TS}$, with an initial volume of $250 \mathrm{~m}^{3}$. If the volume at failure (year 7.78) was extrapolated back to the origin (as has been done in other sludge accumulation studies), the apparent linear accumulation in OK1 is $0.0012 \mathrm{~m}^{3} \mathrm{~kg}^{-1} \mathrm{TS}$. If lagoon OK2 is assumed to fail 
Table 4. Observed average feelable sludge elevation, and calculated average feelable sludge stage and volume in lagoon OK2 from 23 May 1996 to 10 June 2003.

\begin{tabular}{|c|c|c|c|c|c|}
\hline Sampling Date & $\begin{array}{c}\text { Age } \\
\text { (years) }\end{array}$ & $\begin{array}{c}\text { Bottom } \\
\text { Elevation }(\mathrm{m}), \\
\text { mean }(\mathrm{SD})\end{array}$ & $\begin{array}{l}\text { Feelable Sludge } \\
\text { Elevation }(\mathrm{m}), \\
\text { mean }(\mathrm{SD})\end{array}$ & $\begin{array}{c}\text { Feelable Sludge } \\
\text { Thickness } \\
\text { (m) }\end{array}$ & $\begin{array}{c}\text { Feelable Sludge } \\
\text { Volume } \\
\left(\mathrm{m}^{3}\right)\end{array}$ \\
\hline 23 May 1996 & 1.46 & $0.10,0.078$ & $0.27,0.16$ & 0.17 & 170 \\
\hline 13 May 1997 & 2.42 & $0.04,0.041$ & $0.30,0.16$ & 0.26 & 260 \\
\hline 10 August 1999 & 4.65 & $0.07,0.031$ & $0.26,0.30$ & 0.19 & 190 \\
\hline 20 June 2000 & 5.48 & $0.05,0.0465$ & $0.98,0.30$ & 0.92 & 1,100 \\
\hline 19 June 2001 & 6.46 & $0.20,0.032$ & $1.17,0.41$ & 0.97 & 1,150 \\
\hline 21 May 2002 & 7.37 & $0.05,0.028$ & $1.53,0.293$ & 1.48 & 1.950 \\
\hline 10 June 2003 & 8.41 & $0.31,0.34$ & $1.73,0.46$ & 1.41 & 1,830 \\
\hline
\end{tabular}

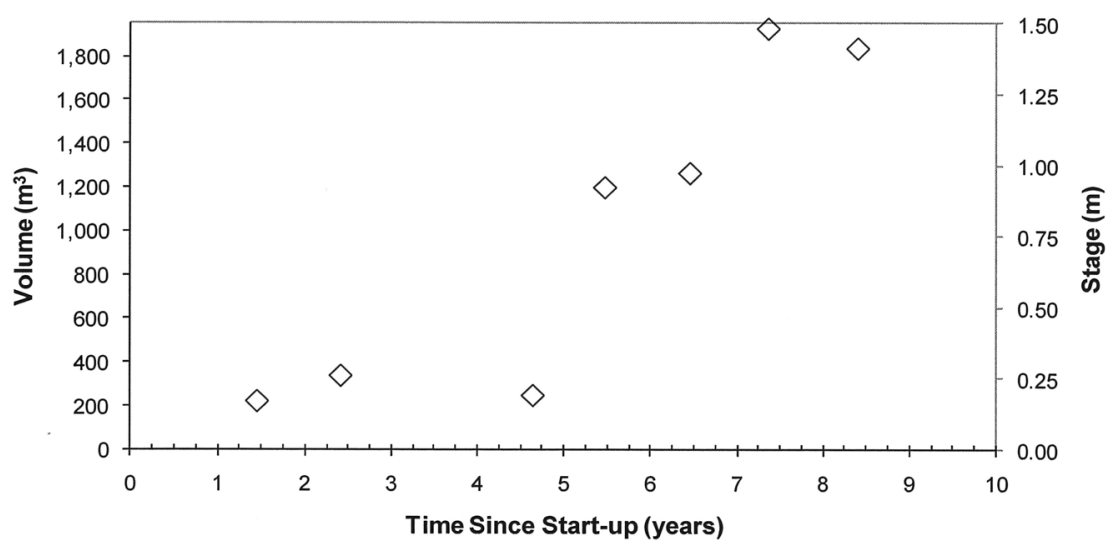

Figure 5. Feelable sludge stage and volume versus time since start-up, lagoon OK2.

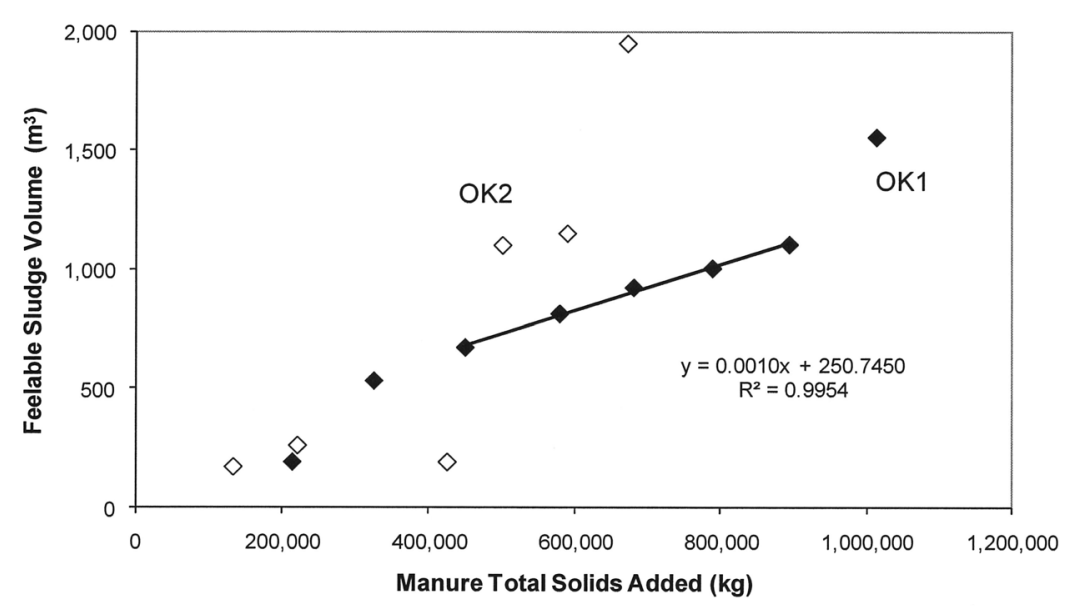

Figure 6. Sludge volume versus total solids loading for lagoons OK1 and OK2.

at 6.46 years, then a similar calculation gives a linear accumulation rate of $0.0020 \mathrm{~m}^{3} \mathrm{~kg}^{-1} \mathrm{TS}$. Both linear rates are lower than the $0.00303 \mathrm{~m}^{3} \mathrm{~kg}^{-1}$ TS value used in the ASABE and NRCS standards.

Fulhage et al. (2005) reported sludge accumulation for one 8-year-old lagoon in Missouri. Depth to sludge was measured by lowering a steel disk with a calculated resistance of $0.69 \mathrm{kPa}\left(0.1 \mathrm{lb} \mathrm{in}^{-2}\right)$ into the lagoon until it came to rest. Using this technique, they determined the average sludge thickness on a grid of 60 points. A slope of a line passing through this volume with an origin at $0.0 \mathrm{~m}^{3}$ had a slope of $0.0013 \mathrm{~m}^{3} \mathrm{~kg}^{-1} \mathrm{TS}$. This is nearly identical to the slope of a line using the 7.78 year data of $\mathrm{OK} 1$ forced through zero $\left(0.0012 \mathrm{~m}^{3} \mathrm{~kg}^{-1} \mathrm{TS}\right)$. This should not be surprising given the similar age of this lagoon to OK1.

Tyson et al. (2002) reported an average $0.0016 \mathrm{~m}^{3} \mathrm{~kg}^{-1} \mathrm{TS}$ sludge accumulation rate for swine lagoons $(n=4)$ less than 5 years old in Alabama. Depth to sludge was determined using a "sludge gun", and accumulation was determined by extrapolating volume at time of sampling to time zero. Morton et al. (2003) measured sludge accumulation in swine lagoons in the Texas panhandle. Age of lagoons varied, and depth to sludge was also determined using a "sludge gun". They reported average accumulation rates of $0.0018 \mathrm{~m}^{3} \mathrm{~kg}^{-1}$ TS for nursery farms $(n=15), 0.0020 \mathrm{~m}^{3} \mathrm{~kg}^{-1} \mathrm{TS}$ for finisher farms $(n=15)$, and $0.0034 \mathrm{~m}^{3} \mathrm{~kg}^{-1}$ TS for sow farms $(n=7)$. 


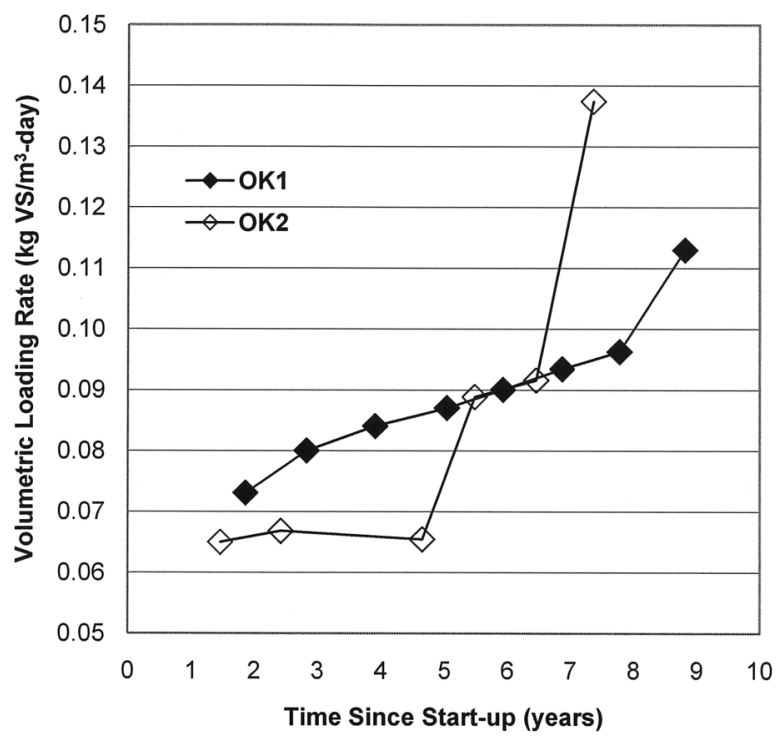

Figure 7. Sludge-free volumetric loading rate versus time since start-up for lagoons OK1 and OK2.

The higher rates of accumulation measured by Tyson and Morton may be due to the fact that the "sludge gun" recorded higher sludge stages than a method based on feel or standard resistance.

\section{Cause of Rapid Solids Accumulation}

Barth and Kroes (1985) and the current design standards (USDA-NRCS, 1992; ASAE Standards, 2004) base lagoon failure on a critical sludge-free volumetric organic loading rate. Three other plausible hypotheses are: hydraulic detention time in the liquid layer becomes too short to sustain communities of microorganisms; sludge solids advance into the mixing zone of the lagoon, blocking sunlight and reducing the photosynthetic activity in the liquid layer; and sludge solids advance into an aerobic layer, reducing the ability of anaerobic bacteria to digest manure solids.

Sludge-free liquid volumetric loading rate, percent of lagoon volume occupied by sludge, and separation distance between the average sludge stage and minimum drawdown volume are plotted versus lagoon age for OK1 and OK2 in figures 7, 8, and 9. Due to their similar geometries and loading rates, it is not surprising that onset of rapid sludge accumulation occurred at similar points in the lagoons' operational lives. Both lagoons began to fail at organic loading rates between 0.090 and $0.095 \mathrm{~kg} \mathrm{VS} \mathrm{m}^{-3} \mathrm{~d}^{-1}$, which is in line with the values used by the Oklahoma NRCS in their design (0.092 to $0.093 \mathrm{~kg} \mathrm{VS} \mathrm{m}^{-3} \mathrm{~d}^{-1}$ ). Both lagoons failed when sludge accumulation approached $30 \%$ of the drawdown volume of the lagoon. Rapid accumulation began as sludge encroached within 1.0 and $1.25 \mathrm{~m}$ of the maximum drawdown level.

\section{CONCLUSION}

It is impossible to draw definitive conclusions on the accumulation of sludge in all lagoons due to the small number and similar characteristics of the lagoons used in this study. These results suggest, however, that accumulation follows the pattern theorized by the complex accumulation model

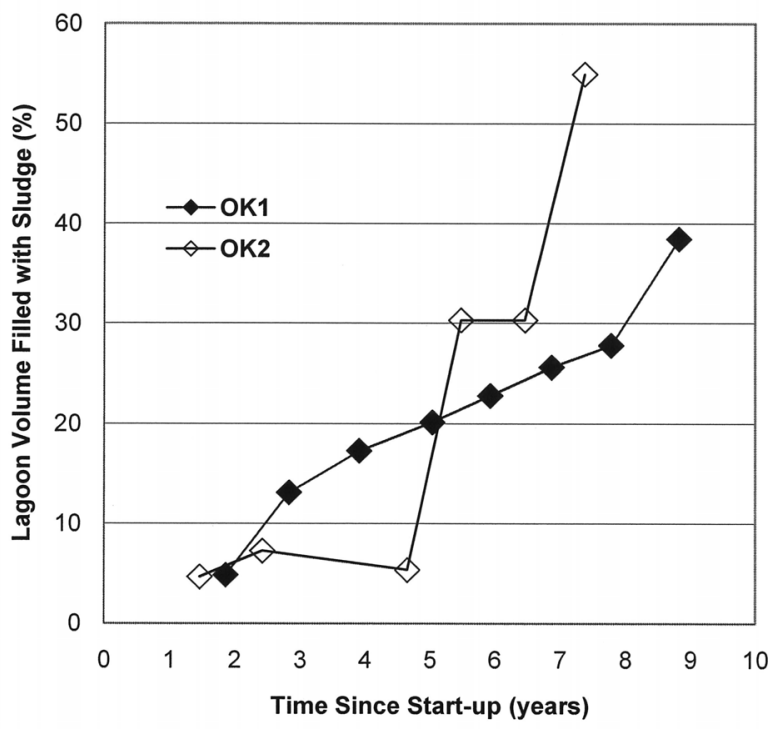

Figure 8. Percent of lagoon volume filled with sludge versus time since start-up for lagoons OK1 and OK2.

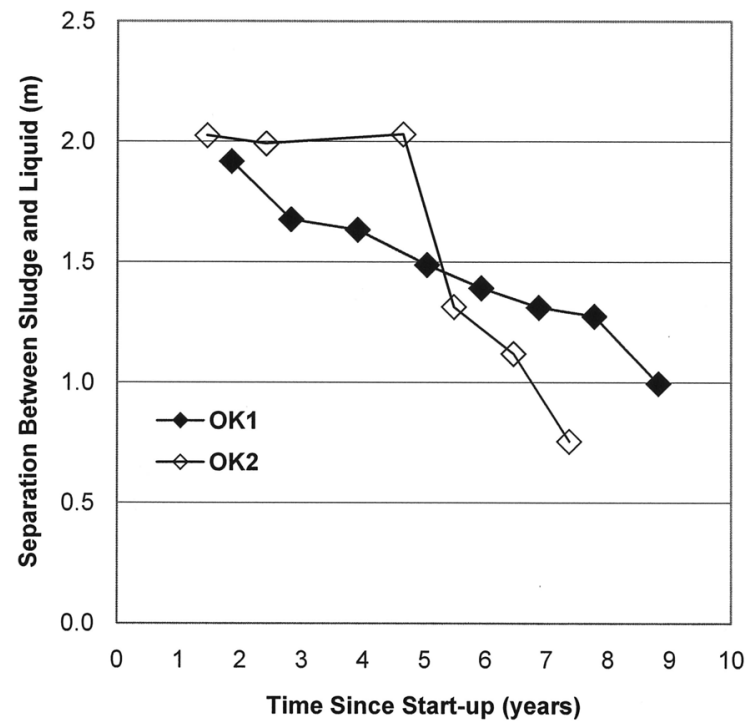

Figure 9. Separation distance between top of sludge and minimum drawdown level versus time since start-up for lagoons OK1 and OK2.

when sludge is allowed to accumulate undisturbed. In addition, contrary to perception, removal of solids during irrigation may increase the rate of sludge accumulation. The results of this research, taken along with previous studies of swine treatment lagoons, suggest that the linear accumulation rate of swine treatment lagoon sludge is less than the $0.00303 \mathrm{~m}^{3} \mathrm{~kg}^{-1}$ TS found in current NRCS and ASABE standards.

These results, taken together with the results of previous studies, suggest that standard linear sludge accumulation rates can be lowered to $0.0012 \mathrm{~m}^{3} \mathrm{~kg}^{-1} \mathrm{TS}$ for swine manure treatment lagoons, provided that the sludge is not disturbed during operation and the storage period is longer than 10 years. The critical volumetric organic loading rate of $0.10 \mathrm{~kg} \mathrm{VS} \mathrm{m}^{-3} \mathrm{~d}^{-1}$, modified for climate variation, appears to adequately predict the point of lagoon failure. Furthermore, altering design standards to maintain a minimum 
separation distance between top of sludge and minimum drawdown level greater than $2.0 \mathrm{~m}$ (Hamilton et al., 2006) does not appear to be justified.

\section{REFERENCES}

Anderson, J. B., D. T. Hill, and T. W. Tyson. 2000. Physical and chemical properties of undisturbed stratified sludge in swine waste anaerobic lagoons. In Proc. 8th Intl. Symp.: Animal, Agricultural, and Food Processing Wastes, 171-178. St. Joseph, Mich.: ASAE.

ASAE Standards. 2004. ANSI/ASAE EP403.3: Design of anaerobic lagoons for animal waste management. St. Joseph, Mich.: ASAE.

ASABE Standards. 2005. ASABE D384.2: Manure production characteristics. St. Joseph, Mich.: ASABE.

Barth, C. L. 1985. The rational design standard for anaerobic livestock waste lagoons. In Proc. 5th Intl. Symp. on Agricultural Wastes: Agricultural Waste Utilization and Management, 638-647. St. Joseph, Mich.: ASAE.

Barth, C. L., and J. Kroes. 1985. Livestock waste lagoon sludge characterization. In Proc. 5th Intl. Symp. on Agricultural Wastes: Agricultural Waste Utilization and Management, 660-671. St. Joseph, Mich.: ASAE.

Bicudo, J. R., L. M. Safley, and P. W. Westerman. 1999. Nutrient content and sludge volumes in single-cell recycle anaerobic lagoons in North Carolina. Trans. ASAE 42(4): 1087-1093.

Booram, C. V., T. E. Hazen, and R. J. Smith. 1975. Trends and variations in an anaerobic lagoon with recycling. In Proc. $3 r d$ Intl. Symp. on Agricultural Wastes: Managing Livestock Wastes, 537-540. St. Joseph, Mich.: ASAE.

Cumba, H. J. 1998. Development of a daily-balance computer model for estimating hydraulic and electrical conductivity values for anaerobic swine lagoon, Appendices B and C. MS thesis. Stillwater, Okla.: Oklahoma State University.

Fulhage, C. D. 1980. Performance of anaerobic lagoons as swine waste storage and treatment facilities in Missouri. In Proc. 4th Intl. Symposium on Livestock Wastes: Livestock Waste: A Renewable Resource, 225-228. St. Joseph, Mich.: ASAE.
Fulhage, C. D., A. Schmidt, and J. Lory. 2005. Long-term sludge and nutrient accumulation in swine lagoons: A case study. In. Proc. 2005 North Carolina Animal Waste Management Symp. Raleigh, N.C.: North Carolina State University.

Hamilton, D. W., and H. J. Cumba. 2000. Thermal phenomena in animal waste treatment lagoons. In Proc. 8th Intl. Symp.: Animal, Agricultural, and Food Processing Wastes, 672-678. St. Joseph, Mich.: ASAE.

Hamilton D. W., C. D. Fulhage, B. Z. Fathepure, W. D Clarkson, and J. L. Lalman. 2006. Treatment lagoons for animal agriculture. In Animal Agriculture and the Environment: National Center for Manure and Animal Waste Management White Papers, 547-547. Pub. No. 913C0306. St. Joseph, Mich.: ASABE.

Humenik, F. J., and M. R. Overcash. 1976. Design criteria for swine waste treatment systems. EPA-600/2-76-233. Ada, Okla.: Robert S. Kerr Environmental Research Laboratory, Office of Research and Development.

Morton, A. D. G. M. Chapman, N. H. Mullin, and B. M. Auvermann. 2003. Sludge accumulation rate determination and comparison for nursery, sow, and finisher lagoons. ASAE Paper No. 034156. St. Joseph, Mich.: ASAE.

Mukhtar, S., J. L. Ullman, B. M. Auverman, S. E. Feagley, and T. A. Carpenter. 2004. Impact of anaerobic lagoon management of sludge accumulation and nutrient content for dairies. Trans. ASAE 47(1): 251-257.

Nordstedt, R. A., and L. B. Baldwin. 1975. Sludge accumulation and stratification in anaerobic dairy lagoons. Trans. ASAE 18(2): 312-315.

Smith, R. E. 1980. Sludge as a condition indicator of anaerobic lagoons. In Proc. 4th Intl. Symp. on Livestock Wastes: Livestock Waste: A Renewable Resource, 247-251. St. Joseph, Mich.: ASAE.

Tyson, T. W., L. McCray, W. E. Prince, and B. Wilson. 2002. Sludge accumulation rate in Alabama swine lagoons less than 5 years old. ASAE Paper No. 024132. St. Joseph, Mich.: ASAE.

USDA-NRCS. 1992. Agricultural Waste Management Field Handbook. Washington, D.C.: USDA Natural Resources Conservation Service. 